\title{
Studies on the formation of formaldehyde during 2-ethylhexyl 4-(dimethylamino)benzoate demethylation in the presence of reactive oxygen and chlorine species
}

\author{
Waldemar Studziński ${ }^{1} \cdot$ Alicja Gackowska ${ }^{1}$. \\ Maciej Przybyłek $^{2} \cdot$ Jerzy Gaca $^{1}$
}

Received: 8 September 2016 / Accepted: 18 January 2017 / Published online: 29 January 2017

(C) The Author(s) 2017. This article is published with open access at Springerlink.com

\begin{abstract}
In order to protect the skin from UV radiation, personal care products (PCPS) often contain chemical UVfilters. These compounds can enter the environment causing serious consequences on the water ecosystems. The aim of this study was to examine, the effect of different factors, such as UV light, the presence of $\mathrm{NaOCl}$ and $\mathrm{H}_{2} \mathrm{O}_{2}$ on the formaldehyde formation during popular UV filter, 2ethylhexyl 4-(dimethylamino)benzoate (ODPABA) demethylation. The concentration of formaldehyde was determined by VIS spectrophotometry after derivatization. The reaction mixtures were qualitatively analyzed using GC/MS chromatography. The highest concentration of formaldehyde was observed in the case of ODPABA/ $\mathrm{H}_{2} \mathrm{O}_{2} / \mathrm{UV}$ reaction mixture. In order to describe two types of demethylation mechanisms, namely, radical and ionic, the experimental results were enriched with Fukui function analysis and thermodynamic calculations. In the case of non-irradiated system containing ODPABA and $\mathrm{NaOCl}$, demethylation reaction probably proceeds via ionic mechanism. As it was established, amino nitrogen atom in the
\end{abstract}

Responsible editor: Gerhard Lammel

Electronic supplementary material The online version of this article (doi:10.1007/s11356-017-8477-8) contains supplementary material, which is available to authorized users.

Maciej Przybyłek

m.przybylek@cm.umk.pl

1 Faculty of Chemical Technology and Engineering, University of Technology and Life Sciences, Seminaryjna 3, 85-326 Bydgoszcz, Poland

2 Department of Physical Chemistry, Faculty of Pharmacy, Ludwik Rydygier Collegium Medicum in Bydgoszcz, Nicolaus Copernicus University in Torun, Kurpińskiego 5, 85-950 Bydgoszcz, Poland
ODPABA molecule is the most susceptible site for the $\mathrm{HOCl}$ electrophilic attack, which is the first step of ionic demethylation mechanism. In the case of irradiated mixtures, the reaction is probably radical in nature. The results of thermodynamic calculations showed that abstraction of the hydrogen from $\mathrm{N}\left(\mathrm{CH}_{3}\right)_{2}$ group is more probable than from 2-ethylhexyl moiety, which indicates higher susceptibility of $\mathrm{N}\left(\mathrm{CH}_{3}\right)_{2}$ to the oxidation.

Keywords Formaldehyde $\cdot$ 2-ethylhexyl 4-(dimethylamino)benzoate $\cdot$ Demethylation $\cdot$ Sunscreen . Reactivity $\cdot$ Disinfection by-products $\cdot$ Reactive oxygen and chlorine species

\section{Introduction}

In the recent 20 years, the annual consumption of pharmaceuticals and personal care products (PPCPs) has dramatically increased (Tong et al. 2011). Among PPCPs, sunscreen agents deserve particular attention. UV filters have been detected in wastewater, surface water (Poiger et al. 2004; Balmer et al. 2005; Ma et al. 2016), sewage sludge (Eljarrat et al. 2012; Zuloaga et al. 2012), river sediments (Amine et al. 2012; Kaiser et al. 2012), bathing waters and swimming pool waters (Vila et al. 2016; Ekowati et al. 2016), and even in drinking water (da Silva et al. 2015). The last example indicates the difficulty of UV filter elimination during waste water treatment. Nowadays, the major concern of UV filter contamination is their effect on the endocrine system of aquatic organisms (Krause et al. 2012; Kinnberg et al. 2015). Another important issue is the environmental fate of sunscreen agents. Recently, there has been a growing interest in the UV filter degradation research (Pattanaargson and Limphong 2001; Díaz-Cruz and Barceló 2009; Nakajima et al. 2009; Santos 
et al. 2012; De Laurentiis et al. 2013; Santos et al. 2013; Gackowska et al. 2014; Hanson et al. 2015; Vione et al. 2015; Gackowska et al. 2016b; Gackowska et al. 2016a; Li et al. 2016; Tsoumachidou et al. 2016). Many of these studies included the effect of oxidizing agents on the sunscreen active ingredient degradation.

Advanced oxidation processes (AOPs) are efficient water treatment methods utilizing reactive oxygen species generation. Some examples of frequently used and studied AOPs are $\mathrm{TiO}_{2} / \mathrm{UV}$ (Hupka et al. 2006; Thiruvenkatachari et al. 2008), $\mathrm{H}_{2} \mathrm{O}_{2}, \mathrm{H}_{2} \mathrm{O}_{2} / \mathrm{UV}, \mathrm{O}_{3}, \mathrm{O}_{3} / \mathrm{UV}$ (Baus et al. 2007; Souza et al. 2016), $\mathrm{Fe}^{2+} / \mathrm{H}_{2} \mathrm{O}_{2}, \mathrm{Fe}^{3+} / \mathrm{H}_{2} \mathrm{O}_{2}$ (Gaca et al. 2005; Tong et al. 2011; Khankhasaeva et al. 2012), $\mathrm{Fe}^{3+} / \mathrm{H}_{2} \mathrm{O}_{2} / \mathrm{UV}$ (Kumar et al. 2008; Diagne et al. 2009; Li et al. 2012b; Topac and Alkan 2016; Tsoumachidou et al. 2016) and $\mathrm{Fe}^{2+} / \mathrm{UV} / \mathrm{S}_{2} \mathrm{O}_{8}{ }^{2-}$ (Khan et al. 2013; Brienza et al. 2014; Xue et al. 2016). Unfortunately, in some cases, AOPs fail in formaldehyde elimination or even contributes to its generation (Can and Gurol 2003; Wert et al. 2007; Trenholm et al. 2008; Tripathi et al. 2011; Li et al. 2012a). However, when considering Fenton-like systems, the effectiveness of formaldehyde removal from its solutions is quite high, even 94\% (Murphy et al. 1989; Kajitvichyanukul et al. 2006; Kowalik 2011; Guimarães et al. 2012; Méndez et al. 2015).

As it was reported (Emri et al. 2004), even very low concentrations of this aldehyde $\left(<10^{-4} \mathrm{M}\right)$ causes DNA damage in human skin cells. The environmental occurrence of formaldehyde is caused by the anthropogenic and nonanthropogenic organic matter oxidation processes, by the release from resins and from other products, to which it is usually added as a preservative (Barker et al. 1996; Salthammer et al. 2010; Madureira et al. 2016; Ochs et al. 2016). One of the possible natural routes of formaldehyde entrance into the environment is through biochemical $O$ - and $\mathrm{N}$-demethylation being a part of metabolic conversions occurring in living organisms (Kalász 2003; Hagel and Facchini 2010; Farrow and Facchini 2013). However, there is also non-biochemical in nature processes of methyl group abstraction. For instance, formaldehyde can be formed as a result of amine demethylation in the presence of a disinfecting agent, $\mathrm{HOCl}$ (Mitch and Schreiber 2008; Kosaka et al. 2014). Furthermore, the formation of low-molecular-weight aldehydes including formaldehyde was postulated in the case of photo-induced radical dealkylation (Bozzi et al. 2002; Görner and Döpp 2003; Baciocchi et al. 2005). It is worth to mention that potential formaldehyde precursors with $\mathrm{N}$-alkylated groups such as drugs (theophylline, caffeine, metamizole, phenazone, aminophenazone), dyes (methylene blue, methyl orange, crystal violet, malachite green), or quaternary ammonium surfactants are widely used in industry and households and therefore can enter the aquatic environment (Boethling 1984; Forgacs et al. 2004; Favier et al. 2015; Zhang et al. 2015). The main purpose of this paper is to evaluate whether degradation of a popular representative of this class, UV filter 2-ethylhexyl 4-(dimethylamino)benzoate, also known as octyl-dimethylp-aminobenzoic acid (ODPABA), can be a potential source of formaldehyde contamination. In order to get a better inside into the nature of ODPABA demethylation, the local reactivity analysis and thermodynamic calculations based on the density functional theory (DFT) were performed. Noteworthy, in the recent decade, quantum-chemical methods including thermodynamic calculations, reaction path modeling, reactivity analysis, and QSAR studies have been increasingly used in environmental studies (Cysewski et al. 2006; Kurtén et al. 2007; Blotevogel et al. 2010; Tröbs et al. 2011; Gaca et al. 2011; Elm et al. 2013; Gackowska et al. 2014; Turkay et al. 2015; Altarawneh and Dlugogorski 2015; Kurtén et al. 2015; Mamy et al. 2015; Xie et al. 2015; Myllys et al. 2016; Gackowska et al. 2016a; Shah and Hao 2016). Fukui function analysis is a robust and effective approach for evaluating the susceptibility of the individual atoms to the nucleophilic, electrophilic, and radical attack (Langenaeker et al. 1992; Pilepić and Uršić 2001; Özen et al. 2003; Martínez et al. 2009; De Witte et al. 2009; Rokhina and Suri 2012; Barr et al. 2012; Saha et al. 2012; Allison and Tong 2013; Altarawneh and Dlugogorski 2015). Previous studies showed that Fukui function can be successfully used in describing degradation and chlorination of a popular sunscreen agent 2-ethylhexyl 4methoxycinnamate (Gackowska et al. 2014; Gackowska et al. 2016a). According to our best knowledge, there is no information in the literature about the ODPABA local reactivity properties and their potential consequences on the environmental fate. Therefore, the additional aim of this paper is to utilize Fukui function analysis to describe ODPABA degradation.

\section{Materials and methods}

\section{Materials}

All chemicals were purchased from commercial suppliers and used without purification. 2-ethylhexyl 4-(dimethylamino)benzoate (ODPABA, CAS: 21245-023) was obtained from Sigma-Aldrich (USA). Sodium hypochlorite $\mathrm{NaOCl}$ with a nominal free chlorine content of $100 \mathrm{~g} / \mathrm{L}$ and $\mathrm{H}_{2} \mathrm{O}_{2}(30 \%)$ were obtained from POCh (Poland).

\section{Reaction conditions}

The reaction mixtures were prepared by dissolving the reactants in $1000 \mathrm{ml}$ of water according to the proportions given in Table 1. The effect of UV irradiation was examined with the use of photoreactor equipped with a Heraeus, TQ 150W 
Table 1 The reaction conditions and substrate proportions used in this study

\begin{tabular}{llllll}
\hline Reagents & ODPABA $[\mathrm{mM}]$ & $\mathrm{H}_{2} \mathrm{O}_{2}[\mathrm{mM}]$ & $\mathrm{NaOCl}[\mathrm{mM}]$ & $\mathrm{UV}[\mathrm{W}]$ & $\mathrm{pH}$ range \\
\hline ODPABA $/ \mathrm{UV}$ & 0.36 & 0 & 0 & 150 & $8.44-8.01$ \\
ODPABA $/ \mathrm{NaOCl}$ & 0.36 & 0 & 10 & - & $10.45-10.29$ \\
ODPABA $/ \mathrm{NaOCl} / \mathrm{UV}$ & 0.36 & 0 & 10 & 150 & $10.30-8.11$ \\
ODPABA $/ \mathrm{H}_{2} \mathrm{O}_{2}$ & 0.36 & 10 & 0 & - & $8.31-8.05$ \\
ODPABA $/ \mathrm{H}_{2} \mathrm{O}_{2} / \mathrm{UV}$ & 0.36 & 10 & 0 & 150 & $8.42-6.82$ \\
\hline
\end{tabular}

medium pressure mercury lamp (200-600 nm), magnetic stirrer (200 rpm), and $\mathrm{pH}$ meter.

\section{Formaldehyde determination}

Formaldehyde was determined in the reaction mixtures using Method 8110 Powder Pillows test kit and DR3900 Benchtop VIS Spectrophotometer provided by Hach, USA. This procedure of formaldehyde determination was designed for water samples by Hach company, based on the older colorimetric method used for air analysis (Matthews and Howell 1981). According to the procedure, the samples are derivatized with 3-methyl-2-benzothiazoline hydrazone (MBTH) using the equipment and chemicals provided in the test kit and then the resulting blue dye is determined through visible spectrophotometry $\left(\lambda_{\max }=630 \mathrm{~nm}\right)$.

\section{GC/MS measurements}

After $180 \mathrm{~min}$, the reaction mixture samples $(50 \mathrm{~mL})$ were extracted for $10 \mathrm{~min}$ by 1:1 n-hexane:ethyl acetate $(10 \mathrm{~mL})$. Then, so-prepared extracts were dried with anhydrous sodium sulfate. The ODPABA transformation products were detected with the use of 5890 HEWLETT PACKARD gas chromatographer equipped with a MS detector and the ZB-5MS column $(0.25 \mathrm{~mm} \times 30 \mathrm{~m} \times 0.25 \mu \mathrm{m})$. The following chromatographic conditions were applied: sample volume $1 \mu \mathrm{L}$, helium carrier gas, injector temperature $250{ }^{\circ} \mathrm{C}$, oven temperature program from 80 to $260{ }^{\circ} \mathrm{C}$ at $10{ }^{\circ} \mathrm{C} / \mathrm{min}$, from 260 to $300{ }^{\circ} \mathrm{C}$ at $5{ }^{\circ} \mathrm{C} /$ $\min$.

\section{Quantum-chemical calculations}

The geometry optimizations, frequencies, and thermochemical calculations were carried out at B3LYP/6-31+ G(d,p) level (Krishnan et al. 1980; McLean and Chandler 1980; Clark et al. 1983; Frisch et al. 1984; Lee et al. 1988; Becke 1988; Miehlich et al. 1989; Becke 1993) with Gaussian03 software (Frisch et al. 2003). In the case of open shell reaction intermediates (radicals), unrestricted procedure (Č́arsky and Hubač 1991) was applied. In order to include the effect of the solvent on the molecular structure, polarized continuum model (PCM) was used (Miertuš et al. 1981; Miertuš and Tomasi 1982). All structures considered in this paper were checked for the absence of imaginary frequencies. Exemplary structural data and frequencies calculated for ODPABA are provided in Online Resource (Tables S1, S2, S3, and S4). Thermodynamic analysis was performed utilizing enthalpy values calculated automatically along with frequencies values according to the approach presented by Ochterski (2000).

Fukui function values (electrophilic $f$, nucleophilic, $f^{+}$and radical $f^{0}$ ) were calculated according to previously reported method (Thanikaivelan et al. 2002; Gackowska et al. 2016a) using BLYP functional (Lee et al. 1988; Becke 1988; Miehlich et al. 1989) with DND basis set (version 3.5) (Delley 2006) and Hirshfeld charge population analysis (Hirshfeld 1977; Ritchie 1985; Ritchie and Bachrach 1987). All these computations were performed within $\mathrm{DMOL}^{3}$ (Delley 1990; Delley 1996; Delley 2000) module of Accelrys Material Studio 7.0 (Accelrys Materials Studio 7 2014). In this study, Fukui function values were calculated according to the Yang and Mortier procedure (Yang and Mortier 1986) using the following Eqs. (1-3):

$$
\begin{aligned}
f^{+} & =Q(n+1)-Q(n) \\
f^{-} & =Q(n)-Q(n-1) \\
f^{0} & =\frac{Q(n+1)-Q(n-1)}{2}
\end{aligned}
$$

where $Q$ denotes the Hirshfeld charge and $n$ the number of electrons in the molecule.

\section{Results and discussion}

At the first stage of the study, the effect of popular water treatment and disinfection agents $\mathrm{H}_{2} \mathrm{O}_{2}, \mathrm{NaOCl}$, and UV irradiation on the formaldehyde formation was examined. The relationships between formaldehyde concentration increase and reaction time is presented on Fig. 1. As we found, the highest concentration of formaldehyde was reached in the case of irradiated samples. It is worth to mention that according to some studies (Mopper and Stahovec 1986; Kieber et al. 1990; Zhou and Mopper 1997; Reader and Miller 2011), there is a relationship between the presence of dissolved organic matter capable of absorbing UV light and formaldehyde contamination. 


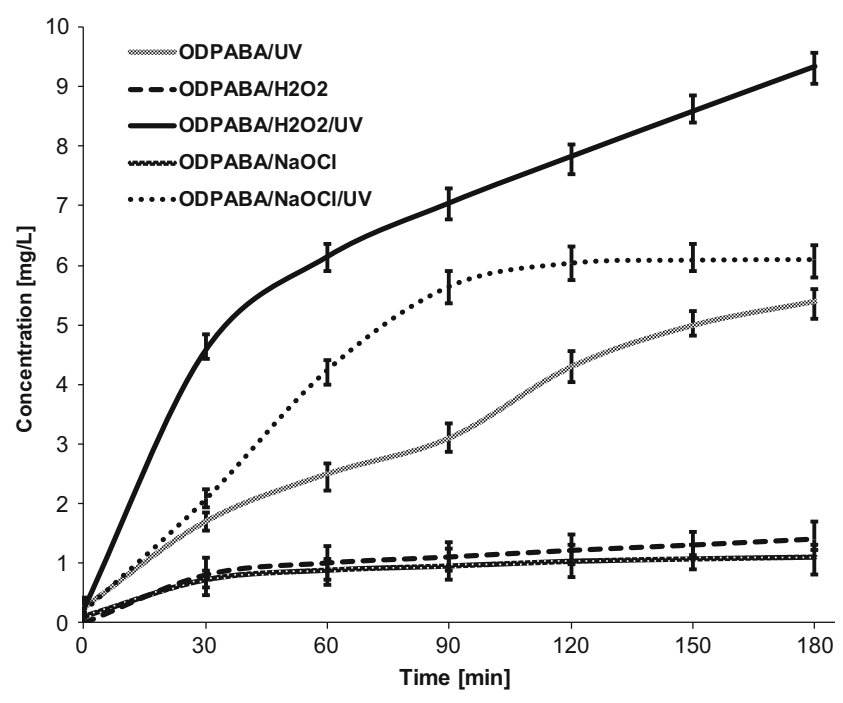

Fig. 1 The effects of different agents on the formation of formaldehyde during ODPABA demethylation

Interestingly, the concentration of formaldehyde in the case of ODPABA/UV system is higher than in the case of ODPABA/ $\mathrm{NaOCl}$ and ODPABA$/ \mathrm{H}_{2} \mathrm{O}_{2}$. This shows that photo-induced demethylation occurs readily even without oxidizing agent addition. In general, two types of photodegradation reactions can be distinguished, namely, direct and indirect. According to the indirect photolysis mechanism, demethylation can be caused by the reactive species formation in the presence of UV filter acting as a photosensitizer. It has been demonstrated that the occurrence of chromophoric dissolved organic matter (CDOM) contributes to the formation of various transients such as carbonate radical $\left(\mathrm{CO}_{3}{ }^{-\bullet}\right)$, hydroxyl radical $\left({ }^{\circ} \mathrm{OH}\right)$, singlet oxygen $\left({ }^{1} \mathrm{O}_{2}\right)$, and excited triplet state ${ }^{3} \mathrm{CDOM}^{*}$ (Schwarzenbach et al. 2005; Vione et al. 2010; Kelly and Arnold 2012; Vione et al. 2014; De Laurentiis et al. 2014; Vione et al. 2015; McNeill and Canonica 2016; Vione 2016). Noteworthy, the presence of ODPABA and $p$-aminobenzoic acid (PABA) significantly enhance singlet oxygen $\left({ }^{1} \mathrm{O}_{2}\right)$ generation in UV-irradiated water (Allen and Gossett 1996). In the case of ODPABA/NaOCl/UV, system demethylation is probably induced by the radical attack of reactive chlorine and oxygen species such as $\mathrm{OH}, \mathrm{Cl}, \mathrm{OCl}$, $\mathrm{O}^{-}, \mathrm{Cl}_{2}^{-}$, and $\mathrm{ClOH}^{-}$formed in the presence of chlorinating agent (Feng et al. 2007; Chan et al. 2012; Fang et al. 2014; Vione et al. 2014). Since ODPABA absorption bands are overlapped with emission spectrum bands of the lamp used in this study (supplementary Fig. S1), direct photodegradation is another potential pathway, which can occur under irradiation conditions. Noteworthy, both direct and indirect mechanisms were found to be a possible explanation of popular sunscreen agent, 2-ethylhexyl 4-methoxycinnamate degradation in surface waters (Vione et al. 2015); however, direct photodegradation was found to be the main route.

As it was reported in previous studies (Sakkas et al. 2003; Nakajima et al. 2009; Calza et al. 2016; Gackowska et al. 2016b), ODPABA demethylation products were formed in the case of ODPABA/UV, ODPABA/NaOCl, and ODPABA/ $\mathrm{NaOCl} / \mathrm{UV}$ systems. The GC/MS analysis presented in this paper confirmed this observation, since identified mass spectra of demethylated degradation ODPABA products are in accordance with literature data (Sakkas et al. 2003). Compounds containing $\mathrm{NH}_{2}$ and $\mathrm{NH}\left(\mathrm{CH}_{3}\right)$ groups were also detected in the case of ODPABA/ $\mathrm{H}_{2} \mathrm{O}_{2}$ and ODPABA/ $\mathrm{H}_{2} \mathrm{O}_{2} /$ UV systems, which have not been studied before. Retention times of detected compounds in the reaction mixtures are given in Table 2. Exemplary mass spectra are provided in Online Resource.

As it was reported (MacManus-Spencer et al. 2011; Gackowska et al. 2014; Gackowska et al. 2016b; Gackowska et al. 2016a), 2-ethylhexyl esters easily undergoes decomposition resulting 2-ethylhexanol. The same observation can be done for the reaction mixtures considered in this study. Since mass spectra of 2-ethylhexyl can be found in the National Institute of Standards and Technology (NIST) database (https://www.nist.gov/), it can be easily identified.

According to fragmentation pathways of ODPABA derivatives presented by Nakajima et al. (2009), a characteristic McLafferty rearrangement can be observed on the mass spectra. As a result of this reaction, ODPABA molecular ion decomposes into neutral 3-methyleneheptane $\left(\mathrm{C}_{8} \mathrm{H}_{16}\right)$ and 4-(N,N-dimethyl)aminobenzoic acid cation radical $(\mathrm{m} / \mathrm{z}=166)$ which corresponds to the most intense peak (Fig. S4 in the Online Resource). Analogical fragmentation behavior is observed in case of demethylated ODPABA derivatives (supplementary Figs. S2, S5, S6, and S7), since mass spectra recorded for those compounds are characterized by the low molecular peaks and the loss of 112 atomic mass units due to the 3-methyleneheptane molecule elimination.

The presence of dichlorinated compounds in ODPABA/ $\mathrm{NaOCl}$ and ODPABA/ $\mathrm{NaOCl} / \mathrm{UV}$ reaction mixtures can be evidenced by the characteristic chlorine isotope signature. Since chlorine occurs in the form of two major isotopes, namely, ${ }^{35} \mathrm{Cl}$ (c.a. $76 \%$ ) and ${ }^{37} \mathrm{Cl}$ (c.a. $24 \%$ ), MS spectra of chlorinated compounds are characterized by the specific patterns. Depending on the number of chlorine atoms in the molecule, a different isotope signature is observed. The presence of two atoms causes the appearance of three $\mathrm{m} / \mathrm{z}$ peaks $\mathrm{M}$ (high intensity), $\mathrm{M}+2$ (lower intensity), and $\mathrm{M}+4$ (the lowest intensity), due to the three isotope combinations $\left({ }^{35} \mathrm{Cl} /{ }^{35} \mathrm{Cl}\right.$, ${ }^{35} \mathrm{Cl} /{ }^{37} \mathrm{Cl}$, and $\left.{ }^{37} \mathrm{Cl} /{ }^{37} \mathrm{Cl}\right)$. Hence, in the case of dichlorinated 2-ethylhexyl 4-(methylamino)benzoate, the most intense peak $(\mathrm{m} / \mathrm{z}=219)$ is near to the MS signals at $\mathrm{m} / \mathrm{z}=221$ and $\mathrm{m} / \mathrm{z}=223$ (supplementary Fig. S6). A similar pattern can be observed for dichlorinated 2-ethylhexyl 4-aminobenzoate (Fig. S7).

Although the use of hydrogen peroxide is preferable from the viewpoint of avoiding unwanted chlorinated compounds, it contributes to the formation of significant quantities of 
Table 2 Retention times and selected MS data of detected compounds

\begin{tabular}{|c|c|c|c|}
\hline Reaction system & Detected compound & Linear formula & $\begin{array}{l}\text { Retention } \\
\text { time (min.) }\end{array}$ \\
\hline \multirow[t]{2}{*}{ ODPABA/UV } & 2-ethylhexyl 4-aminobenzoate & $\mathrm{H}_{2} \mathrm{NC}_{6} \mathrm{H}_{4} \mathrm{COOCH}_{2} \mathrm{CH}\left(\mathrm{C}_{2} \mathrm{H}_{5}\right)\left(\mathrm{CH}_{2}\right)_{3} \mathrm{CH}_{3}$ & 18.02 \\
\hline & 2-ethyl-1-hexanol & $\mathrm{CH}_{3}\left(\mathrm{CH}_{2}\right)_{3}\left(\mathrm{C}_{2} \mathrm{H}_{5}\right) \mathrm{CHCH}_{2} \mathrm{OH}$ & 4.17 \\
\hline \multirow[t]{3}{*}{$\mathrm{ODPABA} / \mathrm{H}_{2} \mathrm{O}_{2}$} & ODPABA & $\left(\mathrm{CH}_{3}\right)_{2} \mathrm{NC}_{6} \mathrm{H}_{4} \mathrm{COOCH}_{2} \mathrm{CH}\left(\mathrm{C}_{2} \mathrm{H}_{5}\right)\left(\mathrm{CH}_{2}\right)_{3} \mathrm{CH}_{3}$ & 19.44 \\
\hline & 2-ethylhexyl 4-(methylamino)benzoate & $\left(\mathrm{CH}_{3}\right) \mathrm{HNC}_{6} \mathrm{H}_{4} \mathrm{COOCH}_{2} \mathrm{CH}\left(\mathrm{C}_{2} \mathrm{H}_{5}\right)\left(\mathrm{CH}_{2}\right)_{3} \mathrm{CH}_{3}$ & 19.11 \\
\hline & 2-ethyl-1-hexanol & $\mathrm{CH}_{3}\left(\mathrm{CH}_{2}\right)_{3}\left(\mathrm{C}_{2} \mathrm{H}_{5}\right) \mathrm{CHCH}_{2} \mathrm{OH}$ & 4.15 \\
\hline \multirow[t]{3}{*}{$\mathrm{ODPABA} / \mathrm{H}_{2} \mathrm{O}_{2} / \mathrm{UV}$} & 2-ethylhexyl 4-(methylamino)benzoate & $\left(\mathrm{CH}_{3}\right) \mathrm{HNC}_{6} \mathrm{H}_{4} \mathrm{COOCH}_{2} \mathrm{CH}\left(\mathrm{C}_{2} \mathrm{H}_{5}\right)\left(\mathrm{CH}_{2}\right)_{3} \mathrm{CH}_{3}$ & 19.24 \\
\hline & 2-ethylhexyl 4-aminobenzoate & $\mathrm{H}_{2} \mathrm{NC}_{6} \mathrm{H}_{4} \mathrm{COOCH}_{2} \mathrm{CH}\left(\mathrm{C}_{2} \mathrm{H}_{5}\right)\left(\mathrm{CH}_{2}\right)_{3} \mathrm{CH}_{3}$ & 18.16 \\
\hline & 2-ethyl-1-hexanol & $\mathrm{CH}_{3}\left(\mathrm{CH}_{2}\right)_{3}\left(\mathrm{C}_{2} \mathrm{H}_{5}\right) \mathrm{CHCH}_{2} \mathrm{OH}$ & 4.16 \\
\hline \multirow[t]{4}{*}{ ODPABA/NaOCl } & dichlorinated 2-ethylhexyl 4-(methylamino)benzoate & $\left(\mathrm{CH}_{3}\right) \mathrm{HNC}_{6} \mathrm{H}_{4} \mathrm{Cl}_{2} \mathrm{COOCH} 2 \mathrm{CH}\left(\mathrm{C}_{2} \mathrm{H}_{5}\right)\left(\mathrm{CH}_{2}\right)_{3} \mathrm{CH}_{3}$ & 20.38 \\
\hline & dichlorinated 2-ethylhexyl 4-aminobenzoate & $\mathrm{H}_{2} \mathrm{NC}_{6} \mathrm{H}_{4} \mathrm{Cl}_{2} \mathrm{COOCH} 2 \mathrm{CH}\left(\mathrm{C}_{2} \mathrm{H}_{5}\right)\left(\mathrm{CH}_{2}\right)_{3} \mathrm{CH}_{3}$ & 19.79 \\
\hline & ODPABA & $\left(\mathrm{CH}_{3}\right)_{2} \mathrm{NC}_{6} \mathrm{H}_{4} \mathrm{COOCH}_{2} \mathrm{CH}\left(\mathrm{C}_{2} \mathrm{H}_{5}\right)\left(\mathrm{CH}_{2}\right)_{3} \mathrm{CH}_{3}$ & 19.50 \\
\hline & 2-ethyl-1-hexanol & $\mathrm{CH}_{3}\left(\mathrm{CH}_{2}\right)_{3}\left(\mathrm{C}_{2} \mathrm{H}_{5}\right) \mathrm{CHCH}_{2} \mathrm{OH}$ & 4.16 \\
\hline \multirow[t]{2}{*}{ ODPABA/NaOCl/UV } & dichlorinated 2-ethylhexyl 4-(methylamino)benzoate & $\left(\mathrm{CH}_{3}\right) \mathrm{HNC}_{6} \mathrm{H}_{4} \mathrm{Cl}_{2} \mathrm{COOCH} 2 \mathrm{CH}\left(\mathrm{C}_{2} \mathrm{H}_{5}\right)\left(\mathrm{CH}_{2}\right)_{3} \mathrm{CH}_{3}$ & 20.27 \\
\hline & 2-ethyl-1-hexanol & $\mathrm{CH}_{3}\left(\mathrm{CH}_{2}\right)_{3}\left(\mathrm{C}_{2} \mathrm{H}_{5}\right) \mathrm{CHCH}_{2} \mathrm{OH}$ & 4.15 \\
\hline
\end{tabular}

formaldehyde (Fig. 1). This is caused by the rapid photodecomposition of $\mathrm{H}_{2} \mathrm{O}_{2}$ yielding hydroxyl radicals $\left(\mathrm{OH}^{\bullet}\right)$. According to the studies on photo-induced dealkylation including demethylation of $p$-substituted $N, N$-dimethylaniline derivatives (Bozzi et al. 2002; Görner and Döpp 2003; Baciocchi et al. 2005; Podsiadly et al. 2007), the reaction proceeds through one-electron oxidation followed by the deprotonation of cation radical resulting in R-Ph-N $\left(\mathrm{CH}_{3}\right)_{2} \mathrm{CH}_{2}{ }^{\bullet}$ radical formation (Fig. 2a). This mechanism seems to be a highly probable explanation of $N, N$-dialkylated aromatic amine photodegradation, since the reaction intermediates namely cation radicals and radicals were observed using spectroscopic methods (Görner and Döpp 2002; Zielonka et al. 2004; Podsiadły et al. 2007). On the other hand, when ODPABA degradation is carried out in the presence of $\mathrm{NaOCl}$, the reaction probably proceeds via ionic mechanism. As it was reported in the literature (Ellis and Soper 1954; Mitch and Schreiber 2008; Kosaka et al. 2014), amine demethylation proceeds via the following steps: electrophilic substitution of $\mathrm{HOCl}$, elimination of $\mathrm{HCl}$, water addition to the $\mathrm{N}=\mathrm{CH}_{2}$ bond, and finally formaldehyde elimination (Fig. 2b).

The local reactivity of particular atoms in the molecule can be quantitatively evaluated using conceptual density functional theory. The higher the value of Fukui function of considered atom, the greater its reactivity. At the next stage of this study, in order to explain the nature of possible ODPABA demethylation mechanisms, quantum-chemical calculations including Fukui function analysis were performed. Since ODPABA can undergo hydrolysis in the environment, the local reactivity analysis was extended for ODPABA degradation product, $p$-(dimethylamino)benzoic acid (DMABA) and its zwitterionic tautomer (DMABA-ZW). The Fukui function values calculated for ODPABA, DMABA, and DMABA-ZW are summarized in Table 3. Optimized structures along with atom numbering scheme are given in Fig. 3.

The $f$ index values calculated for ODPABA and DMABA are the greatest in the case of amino nitrogen atom. Therefore,

a)<smiles>[R]c1ccc(N(C)C)cc1</smiles><smiles>[R]c1ccc([N+](C)(C)CC)cc1</smiles><smiles>[R]c1ccc(N(C)C)cc1</smiles><smiles>[R]c1ccc(N(C)CO)cc1</smiles>

b)
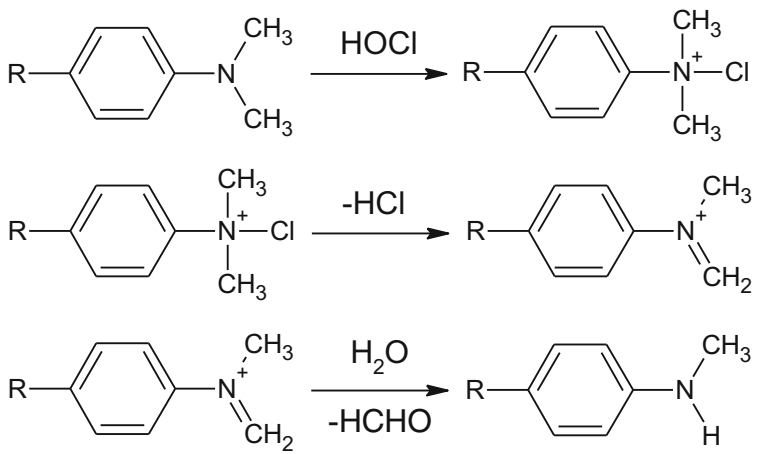

Fig. 2 Radical (a) and ionic (b) demethylation mechanism of amines shown on the example of $p$-substituted $N, N$-dimethylaniline 
Table 3 Radical $f^{\theta}$, nucleophilic $f^{+}$, and electrophilic $f$ Fukui function values calculated for hydrogen atoms in ODPABA, DMABA, and its zwitterionic tautomer DMABA-ZW (atom numbering according to Fig. 3)

\begin{tabular}{|c|c|c|c|c|c|c|c|c|c|c|c|}
\hline \multirow[t]{2}{*}{ Atom } & \multicolumn{3}{|c|}{ ODPABA } & \multirow[t]{2}{*}{ Atom } & \multicolumn{3}{|c|}{ DMABA } & \multirow[t]{2}{*}{ Atom } & \multicolumn{3}{|c|}{ DMABA (ZW) } \\
\hline & $f^{+}$ & $f$ & $f^{0}$ & & $f^{+}$ & $f$ & $f^{0}$ & & $f^{+}$ & $f$ & $f^{0}$ \\
\hline H1 & 0.022 & 0.028 & 0.025 & H1 & 0.023 & 0.028 & 0.026 & $\mathrm{H} 1$ & 0.036 & 0.018 & 0.027 \\
\hline $\mathrm{H} 2$ & 0.023 & 0.040 & 0.032 & $\mathrm{H} 2$ & 0.022 & 0.036 & 0.029 & $\mathrm{H} 2$ & 0.023 & 0.006 & 0.014 \\
\hline $\mathrm{H} 3$ & 0.019 & 0.034 & 0.026 & $\mathrm{H} 3$ & 0.022 & 0.036 & 0.029 & $\mathrm{H} 3$ & 0.024 & 0.007 & 0.016 \\
\hline $\mathrm{H} 4$ & 0.022 & 0.028 & 0.025 & $\mathrm{H} 4$ & 0.023 & 0.028 & 0.026 & $\mathrm{H} 4$ & 0.052 & 0.018 & 0.035 \\
\hline H5 & 0.023 & 0.040 & 0.032 & H5 & 0.022 & 0.036 & 0.029 & $\mathrm{H} 5$ & 0.022 & 0.006 & 0.014 \\
\hline H6 & 0.018 & 0.033 & 0.026 & H6 & 0.022 & 0.036 & 0.029 & H6 & 0.019 & 0.007 & 0.013 \\
\hline $\mathrm{H} 7$ & 0.028 & 0.031 & 0.029 & $\mathrm{H} 7$ & 0.029 & 0.032 & 0.031 & $\mathrm{H} 7$ & 0.040 & 0.030 & 0.035 \\
\hline $\mathrm{H} 8$ & 0.032 & 0.029 & 0.031 & H8 & 0.034 & 0.030 & 0.032 & H8 & 0.030 & 0.026 & 0.028 \\
\hline $\mathrm{H} 9$ & 0.028 & 0.031 & 0.029 & H9 & 0.029 & 0.033 & 0.031 & H9 & 0.034 & 0.028 & 0.031 \\
\hline $\mathrm{H} 10$ & 0.033 & 0.030 & 0.032 & H10 & 0.034 & 0.031 & 0.032 & H10 & 0.029 & 0.026 & 0.027 \\
\hline H11 & 0.014 & 0.010 & 0.012 & H11 & 0.040 & 0.029 & 0.034 & H11 & 0.109 & 0.015 & 0.062 \\
\hline H12 & 0.014 & 0.010 & 0.012 & $\mathrm{C} 12$ & 0.061 & 0.041 & 0.051 & $\mathrm{C} 12$ & 0.048 & 0.023 & 0.035 \\
\hline H13 & 0.003 & 0.001 & 0.002 & C13 & 0.042 & 0.064 & 0.053 & C13 & 0.050 & 0.037 & 0.044 \\
\hline H14 & -0.007 & -0.008 & -0.008 & $\mathrm{C} 14$ & 0.074 & 0.036 & 0.055 & C14 & 0.056 & 0.037 & 0.046 \\
\hline H15 & 0.005 & 0.004 & 0.004 & C15 & 0.042 & 0.066 & 0.054 & C15 & 0.061 & 0.037 & 0.049 \\
\hline H16 & 0.004 & 0.002 & 0.003 & C16 & 0.063 & 0.042 & 0.053 & C16 & 0.042 & 0.022 & 0.032 \\
\hline H17 & 0.008 & 0.005 & 0.007 & $\mathrm{C} 17$ & 0.045 & 0.087 & 0.066 & C17 & 0.076 & -0.008 & 0.034 \\
\hline H18 & 0.009 & 0.007 & 0.008 & N18 & 0.044 & 0.109 & 0.077 & N18 & 0.033 & 0.006 & 0.020 \\
\hline H19 & 0.001 & 0.000 & 0.000 & C19 & 0.017 & 0.028 & 0.023 & C19 & 0.028 & 0.010 & 0.019 \\
\hline $\mathrm{H} 20$ & 0.003 & 0.002 & 0.003 & $\mathrm{C} 20$ & 0.017 & 0.028 & 0.023 & $\mathrm{C} 20$ & 0.038 & 0.010 & 0.024 \\
\hline H21 & 0.007 & 0.006 & 0.006 & $\mathrm{C} 21$ & 0.104 & 0.031 & 0.068 & $\mathrm{C} 21$ & 0.022 & 0.093 & 0.058 \\
\hline $\mathrm{H} 22$ & 0.003 & 0.002 & 0.003 & $\mathrm{O} 22$ & 0.125 & 0.077 & 0.101 & $\mathrm{O} 22$ & 0.066 & 0.274 & 0.170 \\
\hline $\mathrm{H} 23$ & 0.002 & 0.001 & 0.002 & $\mathrm{O} 23$ & 0.067 & 0.034 & 0.050 & $\mathrm{O} 23$ & 0.064 & 0.274 & 0.169 \\
\hline $\mathrm{H} 24$ & 0.002 & 0.002 & 0.002 & & & & & & & & \\
\hline $\mathrm{H} 25$ & 0.004 & 0.003 & 0.003 & & & & & & & & \\
\hline $\mathrm{H} 26$ & 0.007 & 0.006 & 0.006 & & & & & & & & \\
\hline $\mathrm{H} 27$ & 0.003 & 0.002 & 0.003 & & & & & & & & \\
\hline $\mathrm{C} 28$ & 0.097 & 0.024 & 0.060 & & & & & & & & \\
\hline $\mathrm{C} 29$ & 0.072 & 0.034 & 0.053 & & & & & & & & \\
\hline C30 & 0.040 & 0.063 & 0.052 & & & & & & & & \\
\hline C31 & 0.062 & 0.042 & 0.052 & & & & & & & & \\
\hline C32 & 0.048 & 0.086 & 0.067 & & & & & & & & \\
\hline C33 & 0.058 & 0.040 & 0.049 & & & & & & & & \\
\hline C34 & 0.040 & 0.061 & 0.051 & & & & & & & & \\
\hline N35 & 0.041 & 0.112 & 0.077 & & & & & & & & \\
\hline C36 & 0.016 & 0.028 & 0.022 & & & & & & & & \\
\hline $\mathrm{O} 37$ & 0.044 & 0.019 & 0.031 & & & & & & & & \\
\hline O38 & 0.114 & 0.062 & 0.088 & & & & & & & & \\
\hline C39 & 0.001 & 0.000 & 0.000 & & & & & & & & \\
\hline $\mathrm{C} 40$ & 0.003 & 0.002 & 0.003 & & & & & & & & \\
\hline C41 & -0.001 & -0.001 & -0.001 & & & & & & & & \\
\hline $\mathrm{C} 42$ & 0.002 & 0.001 & 0.001 & & & & & & & & \\
\hline $\mathrm{C} 43$ & 0.009 & 0.007 & 0.008 & & & & & & & & \\
\hline $\mathrm{C} 44$ & 0.002 & 0.002 & 0.002 & & & & & & & & \\
\hline $\mathrm{C} 45$ & 0.005 & 0.004 & 0.004 & & & & & & & & \\
\hline $\mathrm{C} 46$ & 0.003 & 0.003 & 0.003 & & & & & & & & \\
\hline $\mathrm{C} 47$ & 0.016 & 0.028 & 0.022 & & & & & & & & \\
\hline
\end{tabular}

one may consider that ODPABA and DMABA readily undergo reactions involving this reactive site. This is not trivial observation since, in the case of aromatic amines, the amino group is conjugated with phenyl ring, which causes reduction of the negative charge density on the nitrogen atom. This effect is even more pronounced in the case of push-pull systems, i.e., when there is an electron accepting substituent attached in para position (as it is in the case of ODPABA and DMBA). Obviously, low negative charge density implies a low susceptibility of the atom to the electrophilic attack. However, in the case of ODPABA and DMBA, the nitrogen atom is even more suitable for electrophilic substitution than orto- $(\mathrm{C} 30, \mathrm{C} 34)$ and para- (C32) positions in phenyl ring. Therefore, $N$-chlorination seems to be more favored than electrophilic substitution on the benzene ring. However, these results do not exclude the possibility of phenyl ring chlorination. Although in general aromatic amines are more prone for $C$ chlorination than for $N$-chlorination, there are some 
Fig. 3 Visual representation of optimized molecular structures of ODPABA (a), DMABA (b), and its zwitterionic tautomer DMABA-ZW (c) along with atom numbering scheme
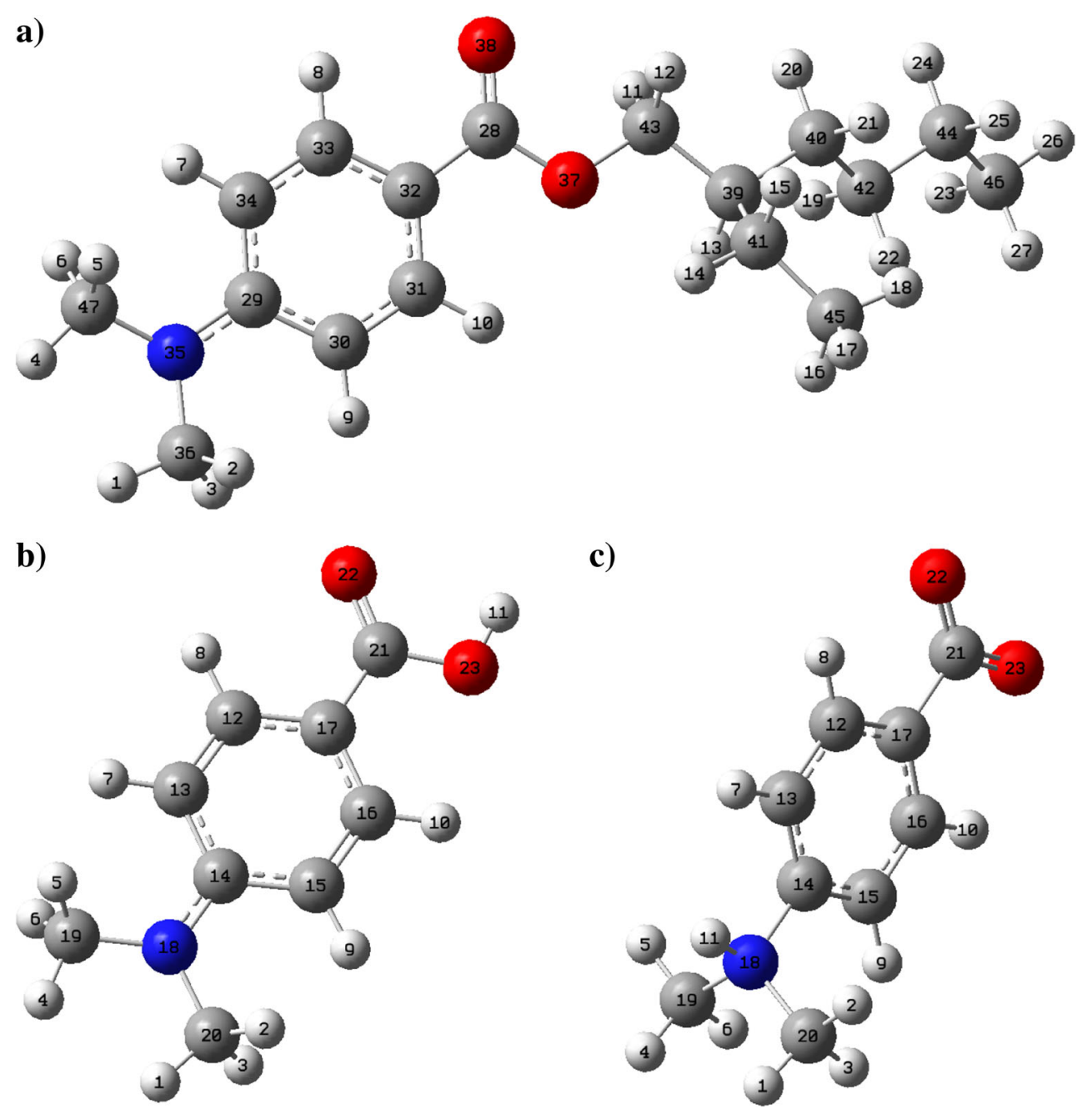

c)

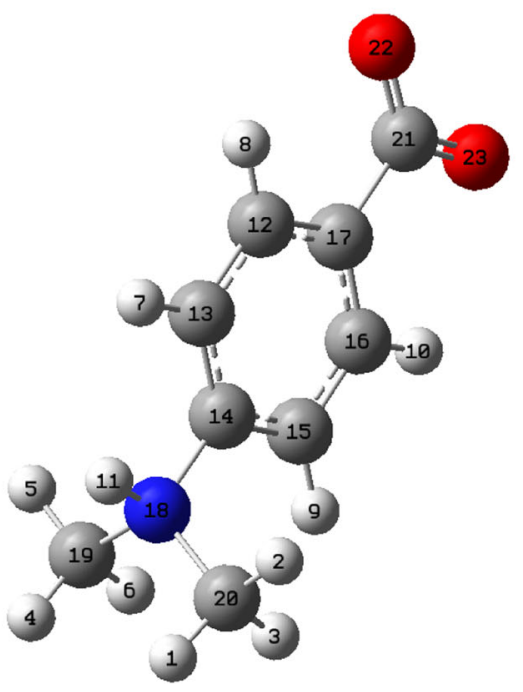

exceptions including drugs with $\mathrm{N}$-alkylated moieties, e.g., fluoroquinolones (Weinberg et al. 2007). The resulting $N$ chlorinated aromatic amines can rearrange to the $C$-chlorinated compounds or decompose. $C$-chlorination is of course a competitive reaction to the $\mathrm{HCl}$ elimination step of demethylation mechanism (Fig. 2b). Noteworthy, as it was reported in the previous works (Sakkas et al. 2003; Gackowska et al. 2016b), both chlorinated and demethylated compounds were formed in ODPABA/ $\mathrm{NaOCl}$ reaction mixture, which is also consistent with the results presented in this study (Table 2). In the case of zwitterionic form of ODPABA hydrolysis product, DMABA-ZW, the nitrogen atom is not susceptible for the electrophilic attack due to the attached H11 proton (Fig. 3c). Noteworthy, the $\mathrm{pK}_{\mathrm{a} 1}$ and $\mathrm{pK}_{\mathrm{a} 2}$ values of DMABA are 6.03 and 11.49, respectively (Haynes et al. 2014), and so, the isoelectric point $\mathrm{pI}$ is 8.76 . Therefore, in the case of ODPABA/ $\mathrm{NaOCl}$ system where the $\mathrm{pH}$ ranges from 10.45 to 10.29 (Table 1), the most dominant form would be neutral DMABA.

As it was mentioned, the R-Ph-N $\left(\mathrm{CH}_{3}\right)_{2} \mathrm{CH}_{2}{ }^{\bullet}$ radical is one of the photo-induced demethylation intermediates (Fig. 2a). According to a different mechanism proposed for Michler ketone demethylation ( $\mathrm{Lu}$ et al. 2009), the initial step of the reaction is radical attack to the hydrogen atom from the $\mathrm{N}\left(\mathrm{CH}_{3}\right)_{2}$ group. It is worth to note that the thermodynamic stability of reactive organic species like radicals and carbocations is an important factor determining which reaction pathway is more kinetically favored. This is so because, according to the Hammond rule (Hammond 1955), transition states are energetically similar to the reaction intermediates. Hence, these reaction paths are more preferred which involve low energy intermediates. The radical formed via hydrogen atom abstraction from the $\mathrm{N}\left(\mathrm{CH}_{3}\right)_{2}$ group is probably highly stabilized by the $\pi$-electron delocalization. Selected resonance structures illustrating unpaired electron delocalization in R-Ph$\mathrm{N}\left(\mathrm{CH}_{3}\right)_{2} \mathrm{CH}_{2} \bullet$ radical are shown on supplementary Fig. S7 (Online Resource). In order to evaluate the stability of radicals formed via hydrogen atom abstraction from ODBABA molecule, quantum-chemical thermodynamic calculations of the hypothetical reactions with hydroxyl radical were performed (Fig. 4). This analysis showed that $\mathrm{OH}^{\bullet}$ attack to the methyl group attached to nitrogen atom 
Fig. 4 Enthalpy changes of the hydrogen atom abstraction reaction from ODPABA by hydroxyl radical (atom numbering according to Fig. 3a)

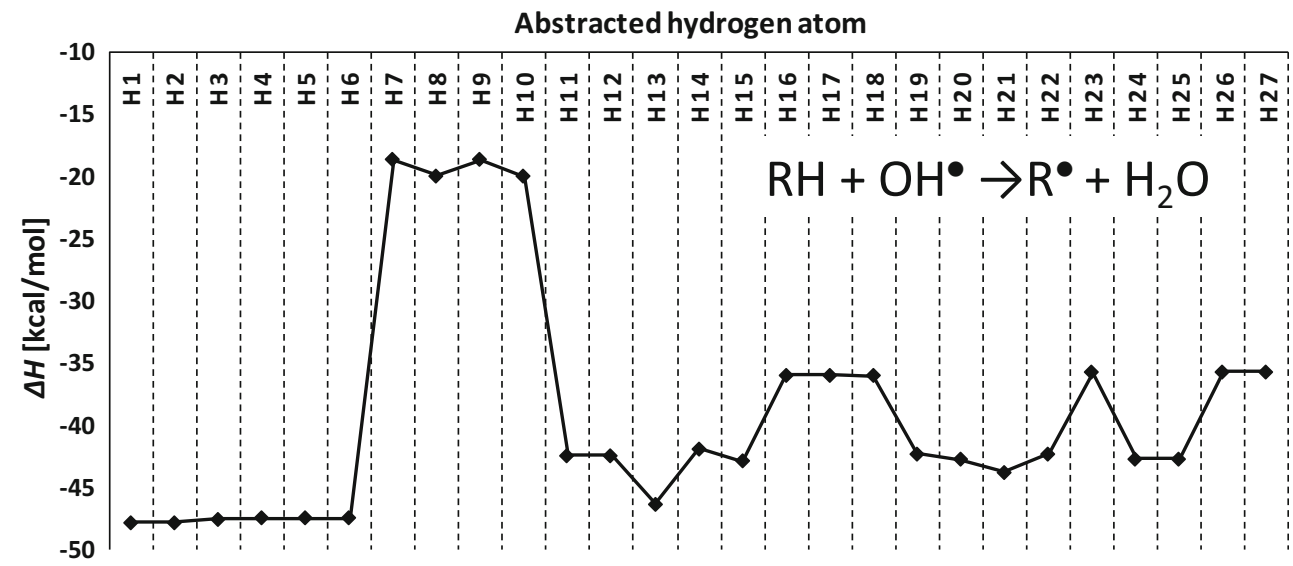

is the most thermodynamically favored (abstraction of $\mathrm{H} 1-\mathrm{H} 6$ atoms). Obviously, formation of phenyl radical is the least probable (H7-H10 abstraction), since it is well known that the radical stability decreases in the order tertiary $>$ secondary $>$ primary $>$ phenyl. As one can see from Fig. 4, the enthalpy change of $\mathrm{OH}^{\bullet}$ attack on the $\mathrm{H} 13$ atom is highly negative in comparison to other hydrogen atoms in 2-ethylhexyl moiety. The significant stability of formed in this reaction tertiary radical can be explained by the hyperconjugation effect. Nevertheless, according to the Fukui function, analysis $\mathrm{OH}^{-}$attack on 2-ethylhexyl moiety is highly unfavorable. As it can be inferred from Table 3, $f^{0}$ values of the 2-ethylhehyl group hydrogen atoms are significantly smaller than in other cases. Therefore, oxidation of methyl groups attached to amino nitrogen is the more preferable pathway of formaldehyde formation than oxidation of methyl groups in 2ethylhexyl moiety.

Although the above local reactivity and thermodynamic analysis was found to be consistent with experimental results, it should be taken into account that calculated values are strongly dependent on the computation level. In this study, a low-computational-cost method, namely, B3LYP/6-31+(d,p), was used. Due to its efficiency, B3LYP is probably the most extensively used functional including UV filter modeling (Alves et al. 2011; Corrêa et al. 2012; Ferreira et al. 2014; Miranda et al. 2014; Gackowska et al. 2014; Garcia et al. 2015; Gackowska et al. 2016a). It is worth mentioning that structures optimized using B3LYP functional and double zeta basis sets were successfully used for UV absorption property prediction of 2-ethylhexyl 4-methoxycinnamate (Alves et al. 2011; Miranda et al. 2014) and benzophenone sunscreen agents (Corrêa et al. 2012). Many studies demonstrated that thermodynamic parameters calculated using B3LYP functional and double zeta basis sets were in good accordance with experimental results (Muñoz-Muñiz and Juaristi 2002; Guner et al. 2003; Li et al. 2003; Ling
Qiu et al. 2006; Chirico et al. 2016). Nevertheless, the B3LYP approach does not include dispersion effects that might be important in the case of the molecules stabilized by the intramolecular interactions (Seebach et al. 2010; Steinmann et al. 2010; DiLabio et al. 2013).

\section{Conclusions}

Since formaldehyde has been recognized as a toxic and carcinogenic compound, it has been numerous attempts to determine the anthropogenic and non-anthropogenic sources of its release to the environment. In this study, a popular UV filter ODPABA degradation in the presence of water treatment and disinfection agents (UV irradiation, $\mathrm{NaOCl}, \mathrm{H}_{2} \mathrm{O}_{2}$ ) was examined. As it was established, the highest concentration of formaldehyde was achieved in the case of irradiated reaction mixtures. This is understandable, since $N$-alkylated aniline derivatives can undergo dealkylation under radical reaction conditions. On the other hand, ODPABA demethylation in the presence of water disinfecting-agent, $\mathrm{NaOCl}$, probably proceeds via ionic mechanism.

Since the environmental fate of chemical compounds is closely related to their reactivity, quantum-chemical calculations can be used as a powerful tool in predicting and describing degradation pathways. It is worth to mention that this approach was utilized in the previous studies dealing with degradation of 2-ethylhexyl methoxy cinnamate (Gackowska et al. 2014; Gackowska et al. 2016a). According to presented herein, Fukui function values analysis, amino nitrogen atom is the most suitable for electrophilic substitution reaction, which is the initial step of ionic mechanism (Ellis and Soper 1954; Mitch and Schreiber 2008; Kosaka et al. 2014). Thermodynamic calculations showed that abstraction of the hydrogen atom from the $\mathrm{N}\left(\mathrm{CH}_{3}\right)_{2}$ group during radical demethylation reaction is more preferable than from 2-ethylhexyl moiety. 
Experimental and theoretical studies on the emerging contamination degradation in the presence of various environmentally relevant agents are helpful in determining which chemical compounds may be formed during real processes taking place in nature and during wastewater treatment. Therefore, carrying out of such research may contribute to better monitoring of toxic compounds in the environment. The presented results in this paper indicate that the presence of ODPABA in water can cause a significant formaldehyde contamination. Therefore, also, other methyl groupcontaining compounds should be tested for the ability of formaldehyde formation when assessing the environmental risk. Since photo-induced ODPABA demethylation occurs readily even without oxidizing and chlorinating agent addition, there is a need to examine the concentration of formaldehyde in bathing and swimming pool waters. Moreover, formaldehyde even in very small amounts can cause DNA damage in the human skin cells (Emri et al. 2004). This is important in the context of possible mutagenic action affected by the release of this compound on the skin from ODPABA containingcosmetics under the influence of UV radiation.

Acknowledgments We thank the Academic Computer Center in Gdańsk for providing its facilities to perform calculations presented in this paper.

Open Access This article is distributed under the terms of the Creative Commons Attribution 4.0 International License (http:// creativecommons.org/licenses/by/4.0/), which permits unrestricted use, distribution, and reproduction in any medium, provided you give appropriate credit to the original author(s) and the source, provide a link to the Creative Commons license, and indicate if changes were made.

\section{References}

Accelrys Materials Studio 7 (2014) Accelrys Materials Studio 7-Inc., San Diego: Accelrys Software Inc.

Allen JM, Gossett CJ (1996) Photochemical formation of singlet molecular oxygen in illuminated aqueous solutions of several commercially available sunscreen active ingredients. Chem Res Toxicol 9:605609. doi:10.1021/tx950197m

Allison TC, Tong YJ (2013) Application of the condensed Fukui function to predict reactivity in core-shell transition metal nanoparticles. Electrochim Acta 101:334-340. doi:10.1016/j. electacta.2012.12.072

Altarawneh M, Dlugogorski BZ (2015) Formation and chlorination of carbazole, phenoxazine, and phenazine. Environ Sci Technol 49: 2215-2221. doi:10.1021/es505948c

Alves LF, Gargano R, Alcanfor SKB et al (2011) A chromophoric study of 2-ethylhexyl p-methoxycinnamate. Chem Phys Lett 516:162165. doi:10.1016/j.cplett.2011.09.078

Amine H, Gomez E, Halwani J et al (2012) UV filters, ethylhexyl methoxycinnamate, octocrylene and ethylhexyl dimethyl PABA from untreated wastewater in sediment from eastern Mediterranean river transition and coastal zones. Mar Pollut Bull 64:2435-2442. doi:10.1016/j.marpolbul.2012.07.051
Baciocchi E, Bietti M, Gerini MF, Lanzalunga O (2005) Electron-transfer mechanism in the N-demethylation of $\mathrm{N}, \mathrm{N}$-dimethylanilines by the phthalimide-N-oxyl radical. J Org Chem 70:5144-5149. doi:10.1021/jo0503916

Balmer ME, Buser H-R, Müller MD, Poiger T (2005) Occurrence of some organic UV filters in wastewater, in surface waters, and in fish from Swiss Lakes. Environ Sci Technol 39:953-962. doi:10.1021/es040055r

Barker JR, Herstrom AA, Tingey DT (1996) Formaldehyde: environmental partitioning and vegetation exposed. Water Air Soil Pollut 86:7191. doi: $10.1007 / \mathrm{BF} 00279146$

Barr WJ, Yi T, Aga D et al (2012) Using electronic theory to identify metabolites present in $17 \alpha$-ethinylestradiol biotransformation pathways. Environ Sci Technol 46:760-768. doi:10.1021/es201774r

Baus C, Sona M, Brauch HJ (2007) Ozonation and combined ozone/ $\mathrm{H} 2 \mathrm{O} 2$, UV/ozone and UV/H2O2 for treatment of fuel oxygenates MTBE, ETBE, TAME, and DIPE from water - A comparison of removal efficiencies. Water Sci Technol 55:307-311. doi:10.2166/wst.2007.424

Becke AD (1988) Density-functional exchange-energy approximation with correct asymptotic behavior. Phys Rev A 38:3098-3100. doi:10.1103/PhysRevA.38.3098

Becke AD (1993) Density-functional thermochemistry. III. The role of exact exchange. J Chem Phys 98:5648. doi:10.1063/1.464913

Blotevogel J, Borch T, Desyaterik Y et al (2010) Quantum chemical prediction of redox reactivity and degradation pathways for aqueous phase contaminants: an example with HMPA. Environ Sci Technol 44:5868-5874. doi:10.1021/es1006675

Boethling RS (1984) Environmental fate and toxicity in wastewater treatment of quaternary ammonium surfactants. Water Res 18:10611076. doi:10.1016/0043-1354(84)90220-3

Bozzi A, Caronna T, Fontana F et al (2002) Photodecomposition of substituted 4-diethylaminoazobenzenes under visible light irradiation in different solvents. J Photochem Photobiol A Chem 152: 193-197. doi:10.1016/S1010-6030(02)00245-9

Brienza M, Mahdi Ahmed M, Escande A et al (2014) Relevance of a photo-Fenton like technology based on peroxymonosulphate for $17 \beta$-estradiol removal from wastewater. Chem Eng J 257:191199. doi:10.1016/j.cej.2014.07.061

Calza P, Vione D, Galli F et al (2016) Study of the photochemical transformation of 2-ethylhexyl 4-(dimethylamino)benzoate (OD-PABA) under conditions relevant to surface waters. Water Res 88:235-244. doi:10.1016/j.watres.2015.10.015

Can ZS, Gurol M (2003) Formaldehyde formation during ozonation of drinking water. Ozone Sci Eng 25:41-51. doi:10.1080/713610649

Čársky P, Hubač I (1991) Restricted Hartree-Fock and unrestricted Hartree-Fock as reference states in many-body perturbation theory: a critical comparison of the two approaches. Theor Chim Acta 80: 407-425. doi:10.1007/BF01117420

Chan PY, Gamal El-Din M, Bolton JR (2012) A solar-driven UV/ Chlorine advanced oxidation process. Water Res 46:5672-5682. doi:10.1016/j.watres.2012.07.047

Chirico RD, Steele WV, Kazakov AF (2016) Thermodynamic properties of indan: experimental and computational results. J Chem Thermodyn 96:41-51. doi:10.1016/j.jct.2015.12.005

Clark T, Chandrasekhar J, Spitznagel GW, Schleyer PVR (1983) Efficient diffuse function-augmented basis sets for anion calculations. III. The 3-21+G basis set for first-row elements, Li-F. J Comput Chem 4: 294-301. doi:10.1002/jcc.540040303

Corrêa BAM, Gonçalves AS, de Souza AMT et al (2012) Molecular modeling studies of the structural, electronic, and UV absorption properties of benzophenone derivatives. J Phys Chem A 116: 10927-10933. doi:10.1021/jp306130y

Cysewski P, Gackowska A, Gaca J (2006) Experimental and theoretical studies on formation and degradation of chloro organic 
compounds. Chemosphere 63:165-170. doi:10.1016/j. chemosphere.2005.06.061

da Silva CP, Emídio ES, de Marchi MRR (2015) The occurrence of UV filters in natural and drinking water in São Paulo State (Brazil). Environ Sci Pollut Res 22:19706-19715. doi:10.1007/s11356-0155174-3

De Witte B, Van Langenhove H, Hemelsoet K et al (2009) Levofloxacin ozonation in water: rate determining process parameters and reaction pathway elucidation. Chemosphere 76:683-689. doi:10.1016/j. chemosphere.2009.03.048

De Laurentiis E, Minella M, Sarakha M et al (2013) Photochemical processes involving the UV absorber benzophenone-4 (2-hydroxy-4methoxybenzophenone-5-sulphonic acid) in aqueous solution: reaction pathways and implications for surface waters. Water Res 47: 5943-5953. doi:10.1016/j.watres.2013.07.017

De Laurentiis E, Minella M, Maurino V et al (2014) Effects of climate change on surface-water photochemistry: a review. Environ Sci Pollut Res 21:11770-11780. doi:10.1007/s11356-013-2343-0

Delley B (1990) An all-electron numerical method for solving the local density functional for polyatomic molecules. J Chem Phys 92:508517. doi:10.1063/1.458452

Delley B (1996) Fast calculation of electrostatics in crystals and large molecules. J Phys Chem 100:6107-6110. doi:10.1021/jp952713n

Delley B (2000) From molecules to solids with the DMol3 approach. J Chem Phys 113:7756-7764. doi:10.1063/1.1316015

Delley B (2006) Ground-state enthalpies: evaluation of electronic structure approaches with emphasis on the density functional method. J Phys Chem A 110:13632-13639. doi:10.1021/jp0653611

Diagne M, Oturan N, Oturan MA, Sirés I (2009) UV-C light-enhanced photo-Fenton oxidation of methyl parathion. Environ Chem Lett 7: 261-265. doi:10.1007/s10311-008-0162-1

Díaz-Cruz MS, Barceló D (2009) Chemical analysis and ecotoxicological effects of organic UV-absorbing compounds in aquatic ecosystems. TrAC - Trends Anal Chem 28:708-717. doi:10.1016/j. trac.2009.03.010

DiLabio GA, Koleini M, Torres E (2013) Extension of the B3LYPdispersion-correcting potential approach to the accurate treatment of both inter- and intra-molecular interactions. Theor Chem Acc 132:1-13. doi:10.1007/s00214-013-1389-x

Ekowati Y, Buttiglieri G, Ferrero G et al (2016) Occurrence of pharmaceuticals and UV filters in swimming pools and spas. Environ Sci Pollut Res 23:14431-14441. doi:10.1007/s11356-016-6560-1

Eljarrat E, Díaz-Cruz MS, Farré M et al (2012) Analysis of emerging contaminants in sewage sludge. Springer, Berlin Heidelberg, pp $31-71$

Ellis AJ, Soper FG (1954) Studies of N-halogeno-compounds. Part VI. The kinetics of chlorination of tertiary amines. J Chem Soc:1750 1755. doi:10.1039/jr9540001750

Elm J, Bilde M, Mikkelsen KV (2013) Influence of nucleation precursors on the reaction kinetics of methanol with the $\mathrm{OH}$ radical. J Phys Chem A 117:6695-6701. doi:10.1021/jp4051269

Emri G, Schaefer D, Held B et al (2004) Low concentrations of formaldehyde induce DNA damage and delay DNA repair after UV irradiation in human skin cells. Exp Dermatol 13:305-315. doi:10.1111/j.0906-6705.2004.00157.x

Fang J, Fu Y, Shang C (2014) The roles of reactive species in micropollutant degradation in the UV/free chlorine system. Environ Sci Technol 48:1859-1868. doi:10.1021/es4036094

Farrow SC, Facchini PJ (2013) Dioxygenases catalyze O-demethylation and $\mathrm{O}, \mathrm{O}-$ demethylenation with widespread roles in benzylisoquinoline alkaloid metabolism in opium poppy. J Biol Chem 288:28997-29012. doi:10.1074/jbc.M113.488585

Favier M, Dewil R, Van Eyck K et al (2015) High-resolution MS and MSn investigation of ozone oxidation products from phenazonetype pharmaceuticals and metabolites. Chemosphere 136:32-41. doi:10.1016/j.chemosphere.2015.04.010
Feng Y, Smith DW, Bolton JR (2007) Photolysis of aqueous free chlorine species $\left(\mathrm{HOCl}\right.$ and $\mathrm{OCl}^{-}$) with $254 \mathrm{~nm}$ ultraviolet light. J Environ Eng Sci 6:277-284. doi:10.1139/s06-052

Ferreira PJO, Pinto da Silva L, Miranda MS, Esteves da Silva JCG (2014) Gas-phase molecular structure and energetics of UVB filter 4methylbenzylidene camphor: a computational study. Comput Theor Chem 1033:67-73. doi:10.1016/j.comptc.2014.02.010

Forgacs E, Cserháti T, Oros G (2004) Removal of synthetic dyes from wastewaters: a review. Environ Int 30:953-971. doi:10.1016/j. envint.2004.02.001

Frisch MJ, Pople JA, Binkley JS (1984) Self-consistent molecular orbital methods 25. Supplementary functions for Gaussian basis sets. J Chem Phys 80:3265-3269. doi:10.1063/1.447079

Frisch MJ, Trucks GW, Schlegel HB et al (2003) Gaussian 03, B01. Gaussian Inc., Pittsburgh, PA

Gaca J, Kowalska M, Mróz M (2005) The effect of chloride ions on alkylbenzenesulfonate degradation in the Fenton Reagent. Polish $\mathrm{J}$ Environ Stud 14:23-27

Gaca J, Wejnerowska G, Cysewski P (2011) Mechanism of the acidic hydrolysis of epichlorohydrin. J Phys Org Chem 24:1045-1050. doi:10.1002/poc. 1825

Gackowska A, Przybyłek M, Studziński W, Gaca J (2014) Experimental and theoretical studies on the photodegradation of 2-ethylhexyl 4methoxycinnamate in the presence of reactive oxygen and chlorine species. Cent Eur J Chem 12:612-623. doi:10.2478/s11532-0140522-6

Gackowska A, Przybyłek M, Studziński W, Gaca J (2016a) Formation of chlorinated breakdown products during degradation of sunscreen agent, 2-ethylhexyl-4-methoxycinnamate in the presence of sodium hypochlorite. Environ Sci Pollut Res 23:1886-1897. doi:10.1007/s11356-015-5444-0

Gackowska A, Studziński W, Gaca J (2016b) Effect of sodium hypochlorite on conversions of octyl-dimethyl-paraaminobenzoic acid. Desalin Water Treat 57:1429-1435. doi:10.1080/19443994.2015.1017318

Garcia RD, Maltarollo VG, Honório KM, Trossini GHG (2015) Benchmark studies of UV-vis spectra simulation for cinnamates with UV filter profile. J Mol Model 21:16102940. doi:10.1007/s00894-015-2689-y

Görner H, Döpp D (2002) Photoinduced demethylation of 4-nitro-N, N-dimethylaniline. Photochem Photobiol Sci 1:270-277. doi: $10.1039 / \mathrm{b} 200352 \mathrm{j}$

Görner H, Döpp D (2003) Transients in the photoreduction of dinitroarenes by triethylamine and N,N-dialkylanilines in benzene. J Photochem Photobiol A Chem 159:219-225. doi:10.1016/S10106030(03)00187-4

Guimarães JR, Turato Farah CR, Maniero MG, Fadini PS (2012) Degradation of formaldehyde by advanced oxidation processes. $\mathrm{J}$ Environ Manage 107:96-101. doi:10.1016/j.jenvman.2012.04.024

Guner V, Khuong KS, Leach AG et al (2003) A standard set of pericyclic reactions of hydrocarbons for the benchmarking of computational methods: the performance of ab initio, density functional, CASSCF, CASPT2, and CBS-QB3 methods for the prediction of activation barriers, reaction energetics, and transition state geometries. J Phys Chem A 107:11445-11459. doi: $10.1021 / \mathrm{jp} 035501 \mathrm{w}$

Hagel JM, Facchini PJ (2010) Biochemistry and occurrence of Odemethylation in plant metabolism. Front Physiol 1:1-7. doi: $10.3389 /$ fphys. 2010.00014

Hammond S (1955) A correlation of reaction rates. J Am Chem Soc 77: 334-338. doi:10.1021/ja01607a027

Hanson KM, Narayanan S, Nichols VM, Bardeen CJ (2015) Photochemical degradation of the UV filter octyl methoxycinnamate in solution and in aggregates. Photochem Photobiol Sci 14:16071616. doi:10.1039/c5pp00074b 
Haynes WM, Bruno TJ, Lide DR (2014) Dissociation constants of organic acids and bases. In: CRC handbook of chemistry and physics, 95th edn. CRC Press, Boca Raton, pp 5-94-5-103

Hirshfeld FL (1977) Bonded-atom fragments for describing molecular charge densities. Theor Chim Acta 44:129-138. doi:10.1007/BF00549096

Hupka J, Zaleska A, Janczarek M, Kowalska E, Górska P, Aranowski R (2006) UV/VIS light-enhanced photocatalysis for water treatment and protection. In: Twardowska I, Allen HE, Häggblom MM, Stefaniak S (eds) Soil and water pollution monitoring, protection and remediation, vol. 69 of NATO Science Series. Springer Netherlands, Dordrecht, pp 351-367. doi:10.1007/978-1-40204728-2 23

Kaiser D, Wappelhorst O, Oetken M, Oehlmann J (2012) Occurrence of widely used organic UV filters in lake and river sediments. Environ Chem 9:139-147. doi:10.1071/EN11076

Kajitvichyanukul P, Lu MC, Liao CH et al (2006) Degradation and detoxification of formaline wastewater by advanced oxidation processes. J Hazard Mater 135:337-343. doi:10.1016/j.jhazmat.2005.11.071

Kalász H (2003) Biological role of formaldehyde, and cycles related to methylation, demethylation, and formaldehyde production. Mini Rev Med Chem 3:175-192. doi:10.2174/1389557033488187

Kelly MM, Arnold WA (2012) Direct and indirect photolysis of the phytoestrogens genistein and daidzein. Environ Sci Technol 46: 5396-5403. doi:10.1021/es300041f

Khan JA, He X, Khan HM et al (2013) Oxidative degradation of atrazine in aqueous solution by $\mathrm{UV} / \mathrm{H} 2 \mathrm{O} 2 / \mathrm{Fe} 2+, \mathrm{UV} / \mathrm{S} 2 \mathrm{O} 82-/ \mathrm{Fe} 2+$ and UV/ HSO5-/Fe2+ processes: a comparative study. Chem Eng J 218:376383. doi:10.1016/j.cej.2012.12.055

Khankhasaeva ST, Dambueva DV, Dashinamzhilova ET (2012) Effect of parameters of the $\mathrm{Fe} 3+/ \mathrm{H} 2 \mathrm{O} 2$ catalytic system on the efficiency of oxidative destruction of azo dye acid chrome dark blue. Russ J Appl Chem 85:1064-1069. doi:10.1134/S1070427212070129

Kieber RJ, Zhou X, Mopper K (1990) Formation of carbonyl compounds from UV-induced photodegradation of humic substances in natural waters: fate of riverine carbon in the sea. Limnol Oceanogr 35: 1503-1515. doi:10.4319/lo.1990.35.7.1503

Kinnberg KL, Petersen GI, Albrektsen M et al (2015) Endocrinedisrupting effect of the ultraviolet filter benzophenone-3 in zebrafish, Danio rerio. Environ Toxicol Chem 34:2833-2840. doi:10.1002/etc. 3129

Kosaka K, Asami M, Nakai T et al (2014) Formaldehyde formation from tertiary amine derivatives during chlorination. Sci Total Environ 488-489:325-332. doi:10.1016/j.scitotenv.2014.04.105

Kowalik P (2011) Chemical pretreatment of formaldehyde wastewater by selected advanced oxidation processes (AOPs). Challenges Mod Technol 2:42-48

Krause M, Klit A, Blomberg Jensen M et al (2012) Sunscreens: are they beneficial for health? An overview of endocrine disrupting properties of UV-filters. Int J Androl 35:424-436. doi:10.1111/j.13652605.2012.01280.x

Krishnan R, Binkley JS, Seeger R, Pople JA (1980) Self-consistent molecular orbital methods. XX. A basis set for correlated wave functions. J Chem Phys 72:650-654. doi:10.1063/1.438955

Kumar A, Paliwal M, Ameta R, Ameta SC (2008) Oxidation of fast green FCF by the solar photo-Fenton process. J Iran Chem Soc 5:346-351. doi:10.1007/BF03246129

Kurtén T, Elm J, Prisle NL et al (2015) Computational study of the effect of glyoxal-sulfate clustering on the Henry's law coefficient of glyoxal. J Phys Chem A 119:4509-4514. doi:10.1021/jp510304c

Kurtén T, Torpo L, Ding CG et al (2007) A density functional study on water-sulfuric acid-ammonia clusters and implications for atmospheric cluster formation. J Geophys Res Atmos 112:D04210. doi:10.1029/2006JD007391

Langenaeker W, Demel K, Geerlings P (1992) Quantum-chemical study of the Fukui function as a reactivity index: part 3. Nucleophilic addition to $\alpha, \beta$-unsaturated compounds. J Mol Struct THEOCHEM 259:317330. doi:10.1016/0166-1280(92)87022-R

Lee C, Yang W, Parr RG (1988) Development of the Colle-Salvetti correlation-energy formula into a functional of the electron density. Phys Rev B 37:785-789. doi:10.1103/PhysRevB.37.785

Li X, Shibata E, Nakamura T (2003) Theoretical calculation of thermodynamic properties of polybrominated dibenzo-p-dioxins. J Chem Eng Data 48:727-735. doi:10.1021/JE0256582

Li W, Nanaboina V, Zhou Q, Korshin GV (2012a) Effects of Fenton treatment on the properties of effluent organic matter and their relationships with the degradation of pharmaceuticals and personal care products. Water Res 46:403-412. doi:10.1016/j.watres.2011.11.002

Li XM, Shen TT, Wang DB et al (2012b) Photodegradation of amoxicillin by catalyzed $\mathrm{Fe} 3+/ \mathrm{H} 2 \mathrm{O} 2$ process. J Environ Sci 24:269-275. doi:10.1016/S1001-0742(11)60765-1

Li S, Lu G, Xie Z et al (2016) Sorption and degradation of selected organic UV filters (BM-DBM, 4-MBC, and OD-PABA) in laboratory water-sediment systems. Environ Sci Pollut Res 23:9679-9689. doi:10.1007/s11356-016-6126-2

Qiu L, Xiao H, Gong X et al (2006) Theoretical studies on the structures, thermodynamic properties, detonation properties, and pyrolysis mechanisms of spiro nitramines. J Phys Chem A 110:3797-3807. doi:10.1021/JP054169G

Lu C-S, Mai F-D, Wu Y-C et al (2009) Photocatalytic degradation of Michler's ketone in water by UV light illumination using $\mathrm{TiO} 2$ photocatalyst: Identification of intermediates and the reaction pathway. J Chinese Chem Soc 56:729-740. doi: $10.1002 /$ jecs. 200900109

Ma B, Lu G, Liu F et al (2016) Organic UV filters in the surface water of Nanjing, China: Occurrence, distribution and ecological risk assessment. Bull Environ Contam Toxicol 96:530535. doi:10.1007/s00128-015-1725-z

MacManus-Spencer LA, Tse ML, Klein JL, Kracunas AE (2011) Aqueous photolysis of the organic ultraviolet filter chemical octyl methoxycinnamate. Environ Sci Technol 45:3931-3937. doi:10.1021/es103682a

Madureira J, Paciência I, Cavaleiro-Rufo J, de Oliveira FE (2016) Indoor pollutant exposure among children with and without asthma in Porto, Portugal, during the cold season. Environ Sci Pollut Res. doi:10.1007/s11356-016-7269-x

Mamy L, Patureau D, Barriuso E et al (2015) Prediction of the fate of organic compounds in the environment from their molecular properties: a review. Crit Rev Environ Sci Technol 45:1277-1377. doi:10.1080/10643389.2014.955627

Martínez C, Sedano M, Mendoza J et al (2009) Effect of aqueous environment in chemical reactivity of monolignols. A new Fukui function study. J Mol Graph Model 28:196-201. doi:10.1016/j. jmgm.2009.07.002

Matthews TG, Howell TC (1981) Visual colorimetric formaldehyde screening analysis for indoor air. J Air Pollut Control Assoc 31: 1181-1184. doi:10.1080/00022470.1981.10465344

McLean AD, Chandler GS (1980) Contracted Gaussian basis sets for molecular calculations. I. Second row atoms, $Z=11-18$. J Chem Phys 72:5639-5648. doi:10.1063/1.438980

McNeill K, Canonica S (2016) Triplet state dissolved organic matter in aquatic photochemistry: reaction mechanisms, substrate scope, and photophysical properties. Environ Sci Process Impacts 18:13811399. doi:10.1039/C6EM00408C

Méndez JAO, Melián JAH, Araña J et al (2015) Detoxification of waters contaminated with phenol, formaldehyde and phenol-formaldehyde mixtures using a combination of biological treatments and advanced oxidation techniques. Appl Catal B Environ 163:63-73. doi:10.1016/j.apcatb.2014.07.032

Miehlich B, Savin A, Stoll H, Preuss H (1989) Results obtained with the correlation energy density functionals of becke and 
Lee, Yang and Parr. Chem Phys Lett 157:200-206. doi:10.1016 /0009-2614(89)87234-3

Miertuš S, Tomasi J (1982) Approximate evaluations of the electrostatic free energy and internal energy changes in solution processes. Chem Phys 65:239-245. doi:10.1016/0301-0104(82)85072-6

Miertuš S, Scrocco E, Tomasi J (1981) Electrostatic interaction of a solute with a continuum. A direct utilizaion of $\mathrm{AB}$ initio molecular potentials for the prevision of solvent effects. Chem Phys 55:117-129. doi:10.1016/0301-0104(81)85090-2

Miranda MS, Pinto Da Silva L, Esteves Da Silva JCG (2014) UV filter 2ethylhexyl 4-methoxycinnamate: a structure, energetic and UV-vis spectral analysis based on density functional theory. J Phys Org Chem 27:47-56. doi:10.1002/poc.3235

Mitch WA, Schreiber IM (2008) Degradation of tertiary alkylamines during chlorination/chloramination: implications for formation of aldehydes, nitriles, halonitroalkanes, and nitrosamines. Environ Sci Technol 42:4811-4817. doi:10.1021/es703017z

Mopper K, Stahovec WL (1986) Sources and sinks of low molecular weight organic carbonyl compounds in seawater. Mar Chem 19: 305-321. doi:10.1016/0304-4203(86)90052-6

Muñoz-Muñiz O, Juaristi E (2002) Computational determination of the enthalpic and entropic contributions to the conformational preference of monosubstituted cyclohexanes. Molecular mechanics, semiempirical and density functional theory methods and ab initio calculations. J Phys Org Chem 15:808-819. doi:10.1002/poc.544

Murphy AP, Boegli WJ, Price MK, Moody CD (1989) A Fenton-like reaction to neutralize formaldehyde waste solutions. Environ Sci Technol 23:166-169. doi:10.1021/es00179a004

Myllys N, Elm J, Kurtén T (2016) Density functional theory basis set convergence of sulfuric acid-containing molecular clusters. Comput Theor Chem 1098:1-12. doi:10.1016/j.comptc.2016.10.015

Nakajima M, Kawakami T, Niino T et al (2009) Aquatic fate of sunscreen agents octyl-4-methoxycinnamate and octyl-4dimethylaminobenzoate in model swimming pools and the mutagenic assays of their chlorination byproducts. J Heal Sci 55: 363-372. doi: $10.1248 / \mathrm{jhs} .55 .363$

Ochs SM, Furtado LA, Cerqueira WV, Pereira Netto AD (2016) Characterization of the variation of carbonyl compounds concentrations before, during, and after the renovation of an apartment at Niterói, Brazil. Environ Sci Pollut Res 23:15605-15615. doi:10.1007/s11356-016-6657-6

Ochterski JW (2000) Thermochemistry in Gaussian. Gaussian Inc Pittsburgh PA:1-19

Özen AS, Aviyente V, Klein RA (2003) Modeling the oxidative degradation of azo dyes: a density functional theory study. J Phys Chem A 107:4898-4907. doi:10.1021/jp026287z

Pattanaargson S, Limphong P (2001) Stability of octyl methoxycinnamate and identification of its photo-degradation product. Int J Cosmet Sci 23:153-160. doi:10.1046/j.14672494.2001.00071.x

Pilepić V, Uršić S (2001) Nucleophilic reactivity of the nitroso group. Fukui function DFT calculations for nitrosobenzene and 2-methyl2-nitrosopropane. J Mol Struct THEOCHEM 538:41-49. doi:10.1016/S0166-1280(00)00642-4

Podsiadły R, Sokołowska J, Marcinek A (2007) A specific resistance of aminoazo dyes to the oxidative degradation. J Photochem Photobiol A Chem 188:267-271. doi:10.1016/j.jphotochem.2006.12.021

Poiger T, Buser HR, Balmer ME et al (2004) Occurrence of UV filter compounds from sunscreens in surface waters: regional mass balance in two Swiss lakes. Chemosphere 55:951-963. doi:10.1016/j. chemosphere.2004.01.012

Reader HE, Miller WL (2011) Effect of estimations of ultraviolet absorption spectra of chromophoric dissolved organic matter on the uncertainty of photochemical production calculations. J Geophys Res Ocean 116:1-9. doi:10.1029/2010JC006823
Ritchie JP (1985) Electron density distribution analysis for nitromethane, nitromethide, and nitramide. J Am Chem Soc 107:1829-1837. doi:10.1021/ja00293a005

Ritchie JP, Bachrach SM (1987) Some methods and applications of electron density distribution analysis. J Comput Chem 8:499-509. doi: $10.1002 / j \mathrm{jcc} .540080430$

Rokhina EV, Suri RPS (2012) Application of density functional theory (DFT) to study the properties and degradation of natural estrogen hormones with chemical oxidizers. Sci Total Environ 417:280-290. doi:10.1016/j.scitotenv.2011.12.008

Saha S, Dinadayalane TC, Murray JS et al (2012) Surface reactivity for chlorination on chlorinated $(5,5)$ armchair SWCNT: a computational approach. J Phys Chem C 116:22399-22410. doi:10.1021/jp307090t

Sakkas VA, Giokas DL, Lambropoulou DA, Albanis TA (2003) Aqueous photolysis of the sunscreen agent octyl-dimethyl-p-aminobenzoic acid: formation of disinfection byproducts in chlorinated swimming pool water. J Chromatogr A 1016:211-222. doi:10.1016/S00219673(03)01331-1

Salthammer T, Mentese S, Marutzky R (2010) Formaldehyde in the indoor environment. Chem Rev 110:2536-2572. doi:10.1021/cr800399g

Santos AJM, Miranda MS, Esteves da Silva JCG (2012) The degradation products of UV filters in aqueous and chlorinated aqueous solutions. Water Res 46:3167-3176. doi:10.1016/j.watres.2012.03.057

Santos AJM, Crista DMA, Miranda MS et al (2013) Degradation of UV filters 2-ethylhexyl-4-methoxycinnamate and 4-tert-butyl-4'methoxydibenzoylmethane in chlorinated water. Environ Chem 10:127-134. doi:10.1071/EN13012

Schwarzenbach RP, Gschwend PM, Imboden DM (2005) Indirect photolysis: reactions with photooxidants in natural waters and in the atmosphere. In: Environmental organic chemistry. Wiley, Inc., Hoboken, NJ, USA, pp 655-686

Seebach D, Grošelj U, Schweizer WB et al (2010) Experimental and theoretical conformational analysis of 5-benzylimidazolidin-4-one derivatives - a "playground" for studying dispersion interactions and a "windshield-wiper" effect in organocatalysis. Helv Chim Acta 93:1-16. doi:10.1002/hlca.200900376

Shah S, Hao C (2016) Density functional theory study of direct and indirect photodegradation mechanisms of sulfameter. Environ Sci Pollut Res 23:19921-19930. doi:10.1007/s11356-016-6956-y

Souza BM, Souza BS, Guimarães TM et al (2016) Removal of recalcitrant organic matter content in wastewater by means of AOPs aiming industrial water reuse. Environ Sci Pollut Res 23:2294722956. doi:10.1007/s11356-016-7476-5

Steinmann SN, Wodrich MD, Corminboeuf C (2010) Overcoming systematic DFT errors for hydrocarbon reaction energies. Theor Chem Acc 127:429-442. doi:10.1007/s00214-010-0818-3

Thanikaivelan P, Padmanabhan J, Subramanian V, Ramasami T (2002) Chemical reactivity and selectivity using Fukui functions: basis set and population scheme dependence in the framework of B3LYP theory. Theor Chem Acc 107:326-335. doi:10.1007/s00214-0020352-z

Thiruvenkatachari R, Vigneswaran S, Moon IS (2008) A review on UV/ $\mathrm{TiO} 2$ photocatalytic oxidation process. Korean J Chem Eng 25:64 72. doi:10.1007/s11814-008-0011-8

Tong AYC, Peake BM, Braund R (2011) Disposal practices for unused medications around the world. Environ Int 37:292298. doi:10.1016/j.envint.2010.10.002

Topac BS, Alkan U (2016) Comparison of solar/H2O2 and solar photofenton processes for the disinfection of domestic wastewaters. KSCE J Civ Eng 20:2632-2639. doi:10.1007/s12205-016-0416-6

Trenholm RA, Rosario-Ortiz FL, Snyder SA (2008) Analysis of formaldehyde formation in wastewater using on-fiber derivatization-solidphase microextraction-gas chromatography-mass spectrometry. J Chromatogr A 1210:25-29. doi:10.1016/j.chroma.2008.09.044 
Tripathi S, Pathak V, Tripathi DM, Tripathi BD (2011) Application of ozone based treatments of secondary effluents. Bioresour Technol 102:2481-2486. doi:10.1016/j.biortech.2010.11.028

Tröbs L, Henkelmann B, Lenoir D et al (2011) Degradative fate of 3chlorocarbazole and 3,6-dichlorocarbazole in soil. Environ Sci Pollut Res 18:547-555. doi:10.1007/s11356-010-0393-0

Tsoumachidou S, Lambropoulou D, Poulios I (2016) Homogeneous photocatalytic oxidation of UV filter para-aminobenzoic acid in aqueous solutions. Environ Sci Pollut Res. doi:10.1007/s11356-016-7434-2

Turkay O, Inan H, Dimoglo A (2015) Experimental study of humic acid degradation and theoretical modelling of catalytic ozonation. Environ Sci Pollut Res 22:202-210. doi:10.1007/s11356-0143326-5

Vila M, Celeiro M, Lamas JP et al (2016) Determination of fourteen UV filters in bathing water by headspace solid-phase microextraction and gas chromatography-tandem mass spectrometry. Anal Methods 8:7069-7079. doi:10.1039/c6ay01787h

Vione D (2016) Photochemical reactions in sunlit surface waters. In: Applied photochemistry, vol. 92 of the series Lecture Notes in Chemistry. Springer International Publishing, pp 343-376. doi:10.1007/978-3-319-31671-0_7

Vione D, Bagnus D, Maurino V, Minero C (2010) Quantification of singlet oxygen and hydroxyl radicals upon UV irradiation of surface water. Environ Chem Lett 8:193-198. doi:10.1007/s10311-0090208-Z

Vione D, Minella M, Maurino V, Minero C (2014) Indirect photochemistry in sunlit surface waters: photoinduced production of reactive transient species. Chem - A Eur J 20:10590-10606. doi:10.1002/chem.201400413

Vione D, Calza P, Galli F et al (2015) The role of direct photolysis and indirect photochemistry in the environmental fate of ethylhexyl methoxy cinnamate (EHMC) in surface waters. Sci Total Environ 537:58-68. doi:10.1016/j.scitotenv.2015.08.002
Weinberg HS, Pereira VJ, Ye Z (2007) Drugs in drinking water: treatment options. In: Aga DS (ed) Fate of pharmaceuticals in the environment and in water treatment systems. CRC Press, Boca Raton, pp 217 228

Wert EC, Rosario-Ortiz FL, Drury DD, Snyder SA (2007) Formation of oxidation byproducts from ozonation of wastewater. Water Res 41: 1481-1490. doi:10.1016/j.watres.2007.01.020

Xie H-B, Ma F, Wang Y et al (2015) Quantum chemical study on·Clinitiated atmospheric degradation of monoethanolamine. Environ Sci Technol 49:13246-13255. doi:10.1021/acs.est.5b03324

Xue Y, Dong W, Wang X et al (2016) Degradation of sunscreen agent paminobenzoic acid using a combination system of UV irradiation, persulphate and iron(II). Environ Sci Pollut Res 23:4561-4568. doi:10.1007/s11356-015-5631-z

Yang W, Mortier WJ (1986) The use of global and local molecular parameters for the analysis of the gas-phase basicity of amines. J Am Chem Soc 108:5708-5711. doi:10.1021/ja00279a008

Zhang C, Cui F, Zeng GM, Jiang M, Yang ZZ, Yu ZG, Zhu MY, Shen LQ (2015) Quaternary ammonium compounds (QACs): a review on occurrence, fate and toxicity in the environment. Sci Total Environ 518-519:352-362. doi:10.1016/j.scitotenv.2015.03.007

Zhou X, Mopper K (1997) Photochemical production of low-molecularweight carbonyl compounds in seawater and surface microlayer and their air-sea exchange. Mar Chem 56:201-213. doi:10.1016/S03044203(96)00076-X

Zielonka J, Podsiadły R, Czerwińska M et al (2004) Color changes accompanying one-electron reduction and oxidation of the azo dyes. $\mathrm{J}$ Photochem Photobiol A Chem 163:373-379. doi:10.1016/j. jphotochem.2004.01.006

Zuloaga O, Navarro P, Bizkarguenaga E et al (2012) Overview of extraction, clean-up and detection techniques for the determination of organic pollutants in sewage sludge: a review. Anal Chim Acta 736:7-29. doi:10.1016/j.aca.2012.05.016 